\title{
Scrotal and penile reconstruction using the vacuum-assisted closure device
}

\author{
Ned Snyder IV MD, Lisa J Gould MD PhD
}

\begin{abstract}
N Snyder, LJ Gould. Scrotal and penile reconstruction using the vacuum-assisted closure device. Can J Plast Surg 2005;13(4):205-206.
\end{abstract}

Fournier's gangrene is a necrotizing, soft tissue infection that spreads along the deep external fascial planes of the perineum, scrotum (or vagina), penis, thighs and lower abdomen. Due to the rapid progression of the disease, patients are frequently left with a large integumentary deficit. Treatment of the skin defect has been described in a multitude of ways including split-thickness skin grafting, burying the testes in the thighs, thigh flaps and a variety of myocutaneous and fasciocutaneous flaps. Many of the previously described techniques have worked well for smaller defects and for closure of wounds but fall short of aesthetic reconstruction of sexual organs. Described here is a technique using split-thickness skin grafts, with foam dressings as the bolster. This was performed using the vacuum-assisted closure device (Kinetic Concepts Inc, USA). This technique creates a natural appearing scrotum that holds the testes away from the body, in a physiological manner, and surfaces the penis with a natural appearance, in a functional manner. The technique results in nearly $100 \%$ graft take and greatly decreases length of hospital stay.

Key Words: Gangrene; Penis reconstruction; Scrotal reconstruction; VAC

Cournier's gangrene is a necrotizing, soft tissue infection that

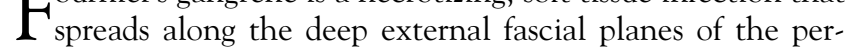
ineum, scrotum (or vagina), penis, thighs and lower abdomen. The first description, of what we now call necrotizing fasciitis, was in 1883 (1). The infection is one of mixed anaerobic organisms facilitating the growth of clostridium spores, which allow the proliferation of facultative anaerobes (2). Treatment of Fournier's gangrene includes the aggressive debridement of infected or devitalized tissue. Due to the rapid progression of the disease, patients are frequently left with a large integumentary deficit. Treatment of the skin defect has been described in a multitude of ways, including split-thickness skin grafting, burying the testes in the thighs, thigh flaps and a variety of myocutaneous and fasciocutaneous flaps (3-7).

Many of the previously described techniques have worked well for smaller defects and for closure of wounds, but fell short of aesthetic reconstruction of sexual organs. Described here is a technique using a vacuum-assisted closure device (VAC [Kinetic Concepts Inc, USA]) and split-thickness skin grafts, with negative pressure dressings as the bolster. The sandwich technique described creates a natural appearing scrotum that holds the testes away from the body, in a physiological manner,

\section{Reconstruction du scrotum et du pénis à l'aide d'un dispositif de fermeture à vide}

La gangrène aiguë de Fournier est une infection nécrosante des tissus mous, qui se propage le long des couches fasciales externes, profondes du périnée, du scrotum (ou du vagin), du pénis, des cuisses et de la partie inférieure de l'abdomen. Comme la maladie se propage rapidement, il en résulte souvent une perte de substance tégumentaire importante. On a tenté de bien des façons de compenser cette perte de substance, notamment par la greffe de demi-épaisseur, l'enfouissement des testicules dans les cuisses, les lambeaux de cuisse et différents types de lambeau myocutané ou fascio-cutané. Plusieurs des techniques précédentes conviennent bien aux petites pertes de substance ou à la fermeture de plaies, mais elles ne permettent pas une reconstruction esthétique des organes sexuels. Voici une technique de reconstruction réalisée à l'aide de lambeaux de demi-épaisseur, de pansements mousse utilisés comme support et d'un dispositif de fermeture à vide (Kinetic Concepts Inc. [États-Unis]). La technique donne une apparence naturelle au scrotum qui garde les testicules à distance du corps d'une manière physiologique et qui fait remonter le pénis à la surface d'une manière naturelle et fonctionnelle. La technique s'est soldée par la prise presque totale de la greffe et a considérablement réduit la durée du séjour à l'hôpital.

and functionally surfaces the penis with a natural appearance. The technique results in nearly $100 \%$ graft take and greatly decreases length of hospital stay.

\section{CASE PRESENTATION}

A 55-year-old man presented to the emergency department four days after being started on levofloxacin for a 'spider bite' to his posterior scrotum and perineum. The affected area had progressed to include all of the skin and soft tissue of his perineum, scrotum, penile shaft (excluding the glans), pubis and lower abdomen. He was urgently taken to the operating room by the urology service and underwent an aggressive debridement of all affected tissues. He had a suprapubic catheter placed at that time. The patient was started on Dakin's $0.025 \%$ moist gauze dressings and appropriate intravenous antibiotics. The plastic surgery service was consulted. After the cellulitis had resolved and all tissues were granulating well, the patient was taken to the operating room on day 20 for reconstruction.

After removal of the dressings, on postoperative day 6 , there was $100 \%$ take of all skin grafts. He was discharged and seen in the clinic at two weeks postoperatively, at which time he completely healed and the suprapubic tube was removed. 


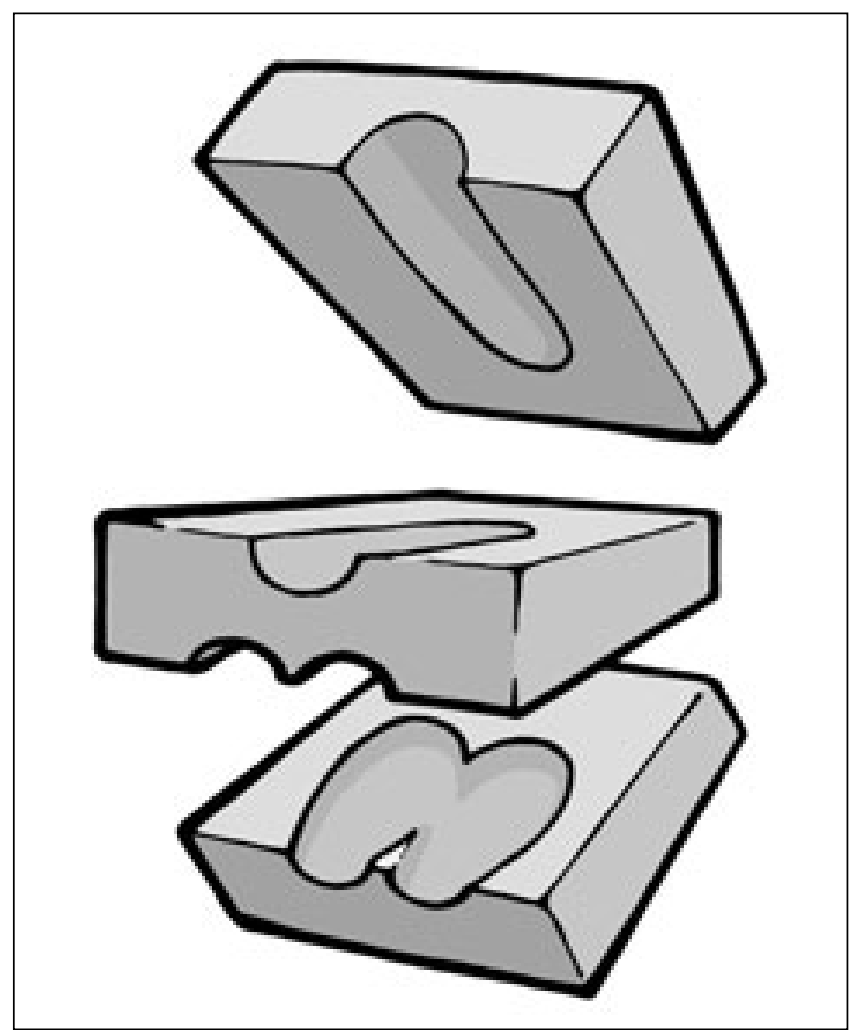

Figure 1) Demonstration of the three-sponge 'sandwich' technique

The patient was last seen at four weeks after reconstruction and had resumed normal sexual activity.

\section{TECHNIQUE}

Under general anesthesia, with the patient in lithotomy position, all open areas were thoroughly irrigated by jet lavage. Minimal debridement was performed. Split-thickness skin grafts were harvested at $0.028 \mathrm{~cm}$, using a Zimmer dermatome (Zimmer Inc, USA), from the anterior thighs. The skin for the scrotum and perineum was meshed 2:1 and placed without stretching over the exposed testes. It was sutured to itself, and to the testes, using 4-0 chromic suture (Ethicon, USA). An unmeshed split-thickness skin graft was piecrusted and wrapped circumferentially around the penis, and sutured to itself and the penis in the midline of the ventral surface, which recreated the median raphe. Adaptic nonadherent gauze was covered with bacitracin and positioned over all skin grafts. The VAC transparent dressing was used to cover all intact skin

\section{REFERENCES}

1. Fournier JA. [Overwhelming gangrene.] Sem Med 1883.

2. Borschel G, Riley R. Necrotizing soft tissue infections and spider bites. In: Achauer BM, ed. Plastic Surgery: Indications, Operations, and Outcomes. St Louis: Mosby, 2000:401.

3. Balakrishnan C. Scrotal avulsion: A new technique of reconstruction by split-skin graft. Br J Plast Surg 1956;9:38-42.

4. Jones RB, Hirschmann JV, Brown GS, Tremann JA. Fournier's syndrome: Necrotizing subcutaneous infection of the male genitalia. J Urol 1979;122:279-82.

5. Monteiro E, Carvalho P, Costa P, Ferraro A. "Inner thigh lift flap" for Fournier gangrene of the scrotum. Plast Reconstr Surg 2002;110:1372-3. over the glans penis. Several black sponges for the VAC were then used to 'sandwich' the penis and testes. As demonstrated in Figure 1, the top sponge had a cutout, or groove, for the penis and was placed on top. Next, a sponge with a groove for the penis on one side and cutouts for the testicles on the other side was placed between the penis and testes. Finally, a sponge with testes cutouts created the inferior portion of the 'sandwich.'

After application of the VAC dressings, negative pressure therapy was instituted continuously at $125 \mathrm{mmHg}$. On postoperative day 6 , the dressings were removed.

\section{DISCUSSION}

Major loss of skin to the scrotum, penis, perineum and pubis poses a difficult reconstructive problem to the reconstructive surgeon and is psychologically devastating to the patient. Techniques for split-thickness skin grafting have been described in the past, but with largely unsatisfactory results (8). Implantation of the testes in the thigh, followed by local skin immobilization and scrotal reconstruction, has been associated with testicular atrophy and constant pain from mechanical trauma (9). The VAC has been used as a negative pressure bolster over split thickness skin grafts with good results (10). The negative pressure dressing minimizes shear, fluid collection and promotes plasmatic imbibition. These benefits are accentuated, whereas traditional bolster methods or graft stabilization techniques are not easily applied. In areas such as the knee or axilla, the VAC has been demonstrated to be quite useful for skin graft stabilization. The present case demonstrates our technique for use of a VAC bolster over skin grafts for reconstruction of the penis and scrotum after Fournier's gangrene. We have found that, on areas of the body with contours that are difficult to bolster, improved graft take can be achieved using the negative pressure dressing. Rapid healing of these wounds results in a less hypertrophic and contracted scar. In addition to the case presented here, VAC therapy has become our standard of care for groin, perineal and axillary skin grafts after excision of hidradenitis suppurativa. Studies are currently underway to assess skin graft pliability and postgraft range of motion after axillary split-thickness skin grafts with and without the VAC.

ACKNOWLEDGEMENTS: The authors thank Robert L Hynecek for his artistic contributions.

Presented at the Wound Healing Society $14^{\text {th }}$ Annual Meeting, Atlanta, Georgia, May 23-26, 2004.

6. Young WA, Wright JK. Scrotal reconstruction with a rectus abdominis muscle flap. Br J Plast Surg 1988;41:190-3.

7. Maharaj D, Naraynsingh V, Perry A, Ramdass M. The scrotal reconstruction using the "Singapore Sling". Plast Reconstr Surg 2002;110:203-5.

8. Tiwari IN, Seth HP, Mehdiratta KS. Reconstruction of the scrotum by thigh flaps. Plast Reconstr Surg 1980;66:605-7.

9. Moustafa MF. Gangrene of the scrotum: An analysis of ten cases. Br J Plast Surg 1967;20:90-6.

10. Blackburn JH 2nd, Boemi L, Hall WW, et al. Negative-pressure dressings as a bolster for skin grafts. Ann Plast Surg 1998;40:453-7. 